\title{
Corporeidades Identitárias no Xirê
}

\author{
Corporeidades Identitárias en el 'Xirế' \\ Identity Corporeities in 'Xirế'
}

\begin{abstract}
Resumo
Este trabalho relata experiências de um professor de Arte da educação básica da rede pública do Distrito Federal. Apresenta noções de corporeidades sob a perspectiva iorubana presente no Brasil, dialogando com a Etnocenologia e com os Estudos Decoloniais. Objetiva refletir sobre as práticas e comportamentos humanos espetaculares organizados produzidos para ressignificar identidades nas relações de poder da colonialidade. $\mathrm{O}$ diálogo proposto aponta o xirê como prática ritualística candomblecista onde acontecem aprendizagens estéticas que redimensionam conceitos de corporeidades negras e potencializam vivências educativas decoloniais. Este texto consiste, sobretudo, em um exercício de tradução a partir do ponto de vista da ecologia de saberes. A metodologia focada na auto-etnografia e na trajetividade busca estabelecer conexões intersubjetivas em que os saberes produzidos prezam pelo reconhecimento do saber sensível presente na expressividade corporal como experiência geradora de conhecimento.
\end{abstract}

Palavras-Chave: Corporeidade; Educação; Estudos Decoloniais; Etnocenologia; Identidade.

\section{Resumen}

Este trabajo relata experiencias de un profesor de Arte de la Educación Básica que trabaja para el Gobierno de Distrito Federal. Presenta nociones de corporeidades bajo la perspectiva iorubana presente en Brasil, dialogando con la Etnocenología y con los Estudos Decoloniales. Tiene como objetivo refletir acerca de las prácticas y comportamientos humanos espectaculares organizados hechos para resignificar identidades en las relaciones de poder de la colonialidad. El diálogo propuesto muestra el Xirê como práctica ritualística candomblecista, donde puede haber aprendizajes estéticos que redimensionan conceptos de corporeidades negras y potencializan experiencias educativas decoloniales. Este texto consiste, sobretodo, en un ejercício de traducción a partir del punto de vista de la ecología de saberes. La metodología enfocada en la autoetnografía y en la trajetividad intenta establecer conexiones intersubjetivas en que los saberes producidos valoran el reconocimiento del saber sensible presente en la expresividad corporal como experiencia geradora de conocimiento.

Palabras claves: Corporeidad; Educación; Estudos Decoloniales; Etnocenología; Identidad.

\begin{abstract}
This paper reports experiences of an Art teacher of the Basic Public Education in Distrito Federal, Brazil. It presents notions of corporeities from Yoruba Culture, perspective present in Brazil, dialoguing with Ethnocenology and Decolonial Studies. The objective is reflect how the spectacular human practices and behaviors are organized and produced to re-signify identities in the power relations of coloniality. The proposed dialogue points the 'xirế' as a candomblecist ritualistic practice where aesthetic learning takes place that restructures concepts of black corporeities and potentiates decolonial educational experiences. This text consists, especially, of an exercise in translation from the point of view of the ecology of knowledges. A

\footnotetext{
${ }^{1}$ Mestre em Arte pela Universidade de Brasília; Professor efetivo da Secretaria de Estado de Educação do Distrito Federal; Brasília, DF, Brasil; e-mail: bbeto.costa@gmail.com. Trabalho apresentado no I Seminário Latino-Americano de Estudos em Cultura - SEMLACult, Foz do Iguaçu/PR, Brasil, 2017.
} 
methodology focused on self-ethnography and trajectory wants to establish intersubjective connections wherein the knowledge produced by the recognition of the sensitive learning present in the body expressivity as knowledge-generating experience.

Keywords: Corporeities; Education;Decolonial Studies; Ethnocenology; Identity.

\section{Introdução}

O artigo Corporeidades Identitárias no Xirê ${ }^{2}$ descreve parte de minhas experiências como professor de Arte da educação básica na rede pública do Distrito Federal e de minhas vivências como iniciado nas práticas ritualísticas candomblecistas. A iniciação no Candomblé provocou-me reflexões sobre as relações raciais e tem ressignificado minha identidade. Por isso, considero essa religião de matriz africana surgida no Brasil como território de resistência às violências do mundo (neo)colonial.

Como pesquisador em Artes Cênicas, utilizo os pressupostos teóricos da Etnocenologia e foco minha investigação na maneira como a teatralidade e a espetacularidade são usadas estrategicamente na resistência aos processos de apagamento identitários. Aponto as vivências corporais ritualísticas negras como práxis que redimensionam identidades e potencializam procedimentos educativos decoloniais. Descrevo como tais mecanismos coletivos de resistência influenciam meu trabalho em sala de aula. Para tanto, elenquei como objetivo propor reflexões sobre as práticas e comportamentos humanos espetaculares organizados oriundos das noções de corporeidade que circulam no xirê e que ressignificam a noção de pessoa.

Este artigo se constitui, sobretudo, em um diálogo entre a Etnocenologia, as considerações de Achille Mbembe e os Estudos Decoloniais. Além disso, trata-se de um exercício de tradução sob a ótica da ecologia de saberes apresentada por Boaventura Santos (2009). Tais perspectivas teóricas oportunizam identificar práticas culturais capazes de decolonizar conceitos sobre o corpo para superar a desumanização dos sujeitos negros. Sabemos que os conhecimentos que não são produzidos pela racionalidade científica imposta pelo colonialismo não são reconhecidos, o que gera um sistema de monocultura. Os saberes produzidos por povos tradicionais de maneira não-científica estão relegados à invisibilidade, produzindo a falsa ideia de que os colonizados não produzem epistemologias.

\footnotetext{
${ }^{2}$ Registro das reflexões propostas na disciplina Tópicos em Educação Ambiental: Estudos (de)coloniais em Educação: Saberes, Territórios e Diferença do Programa de Pós-graduação da Faculdade de Educação da Universidade de Brasília, ministrada pela professora Ana Tereza Reis da Silva no $2^{\text {o }}$ semestre de 2016.
} 
Considerando que a educação acontece no corpo, essa encruzilhada: o locus simbólico da produção dos sentidos, onde as identificações se encontram e de onde partem para novas trajetórias, destaco o papel fundamental das aprendizagens estéticas na produção de uma ecologia de saberes. Para tanto, na metodologia utilizada, priorizo a auto-etnografia (FORTIN, 2009) e a trajetividade (BIÃO, 2009) para estabelecer conexões intersubjetivas em que os saberes produzidos prezam pelo reconhecimento do saber sensível da expressividade corporal como experiência geradora de conhecimento, sem desconsiderar o jogo entre racionalidade e imaginário, racional e sensível, razão e emoção, que não representam oposições, mas dinâmicas de mecanismos que geram conhecimentos.

O artigo está organizado de forma que o leitor encontrará a contextualização do processo de pesquisa, a apresentação da ideia de corpo-altar como proposição que nasce a partir da reflexão articulada entre a prática ritualística e a noção de corpo-túmulo discutida por Achile Mbembe. Para isso, lanço mão da concepção de pessoa e de corporeidade sob a perspectiva da cosmovisão iorubá no Brasil e das narrativas míticas que fundamentam a expressividade corporal presente na dança dos Orixás. Para finalizar, apresento as aprendizagens estéticas do xirê como potente pedagogia decolonial.

\section{Corporeidades Identitárias no Xirê}

Para sobreviverem à rede de violências colonial, homens e mulheres africanos ressignificaram na diáspora negra os diversos rituais praticados na África, restituindo a si próprios a humanidade que lhes foi negada pelo colonizador. Essas práticas ritualísticas preservam noções de corporeidade, de pessoa e de identidade. Neste trabalho, proponho lançarmos um olhar para as noções de corporeidade que permeiam as práticas $e$ comportamentos humanos espetaculares organizados do xirê.

A palavra xirê, de origem iorubá - siré3 ${ }^{3}$, pode ser entendida como brincadeira, jogo, festa. No Candomblé, o termo se refere à cerimônia que se constitui como ápice de uma série de rituais, é o momento festivo em que as divindades e seus convidados celebram os ritos cumpridos. No xirê, os adeptos formam uma roda dançando no sentido anti-horário. São cantadas cantigas específicas em cada xirê, que seguem uma sequência para evocar a presença

\footnotetext{
${ }^{3}$ Faço a opção neste estudo pelo uso de palavras em iorubá. Para uma melhor compreensão e boa leitura, recomendo as seguintes observações: o sistema linguístico iorubá é marcado por acentos em cima das vogais que servem para dar um tom alto quando é usado o acento agudo, um tom baixo com queda na voz quando é usado um acento grave e um tom médio com voz normal quando não é usado nenhum acento. O sinal usado embaixo das vogais "o" - "e" (o - e ) indicam um som aberto e o sinal embaixo da letra "s" (ş) indica o som correspondente ao " $\mathrm{x}$ ” na língua portuguesa. No iorubá, não são usadas as letras C, Q, X, Z, V.
} 
dos Orixás. Acredita-se que essas divindades se manifestam para distribuir sua força vital, o aşé, por meio de danças e de comidas distribuídas na festa. Os Orixás expressam em seus movimentos os saberes estéticos e míticos em que estão presentes as noções de corporeidade.

As nações de Candomblé se formaram a partir dos conhecimentos de três principais grupos de africanos que chegaram ao Brasil: os yorubás, nomeados pelos colonizadores de nagôs, sistematizaram o candomblé de nação Ketu. Os Orixás são as divindades que fazem parte do panteão do povo iorubano e cultuados no Brasil no Candomblé Ketu. Os bantu deram origem à nação Angola e cultuam Inquices. Os ewè-fon originaram a nação Jeje e reverenciam Voduns.

\subsection{Vivências Decoloniais}

Em minha trajetória, levei muitos anos para assumir-me como negro. Afastei-me de minha identidade negando minhas próprias raízes. Somente aproximadamente aos vinte e três anos de idade foi que eu passei a ver-me como afrodescendente. Até então, definia-me como moreno. Cheguei a dizer que era moreno claro. Logo percebi que esse fenômeno acontece também com outros sujeitos afro-brasileiros. Movido por essa inquietação, iniciei uma procura de informações sobre os motivos que nos induzem a negar nossa própria identidade.

Com minha experiência com a religiosidade de matriz africana, foi que comecei a romper com muitos preconceitos que antes me levavam para um lugar de não-negro. Muitas estruturas coloniais ainda enraizadas em mim começaram a ser desconstruídas com as vivências ritualísticas candomblecistas. Na escola, durante trinta e três anos como estudante e professor, poucos elementos identitários afro-brasileiros me foram apresentados para que houvesse uma proximidade a minha negritude. Posso até dizer que aconteceu o contrário, pois preconceitos e estereótipos foram reforçados e muitas vezes provocaram em mim estranhamento e medo da cultura negra.

Um exemplo desse mecanismo escolar revela-se nas lembranças que guardo no uso das imagens de Jean-Baptiste Debret nos livros didáticos. O corpo negro me foi apresentado como um corpo humilhado, castigado, submisso, seminu. As representações corporais produzidas por este artista francês se fixaram em minha memória, naturalizando a escravidão como condição existencial do ser negro e reforçando a ideia de superioridade do colonizador.

A violência retratada na obra Castigo de Escravo (figura 1) e em outras imagens de Debret era algo que me aterrorizava. Na infância, eu ainda não tinha consciência da violência simbólica à qual estava exposto. Hoje, entendo que houve a produção de mecanismos de 
dominação colonial que estabeleceu uma rede de violências, agindo continuadamente para sustentar a colonialidade. Como afirma Achille Mbembe (2014, p. 183), inspirado em Franz Fanon: "a violência colonial é, na realidade, uma rede, 'ponto de encontro de violências múltiplas, diversas, reiteradas, cumulativas', vividas tanto no plano mental como no 'dos músculos e sangue'". Nesse sentido, a colônia é o resultado do extermínio físico e epistemológico do colonizado.

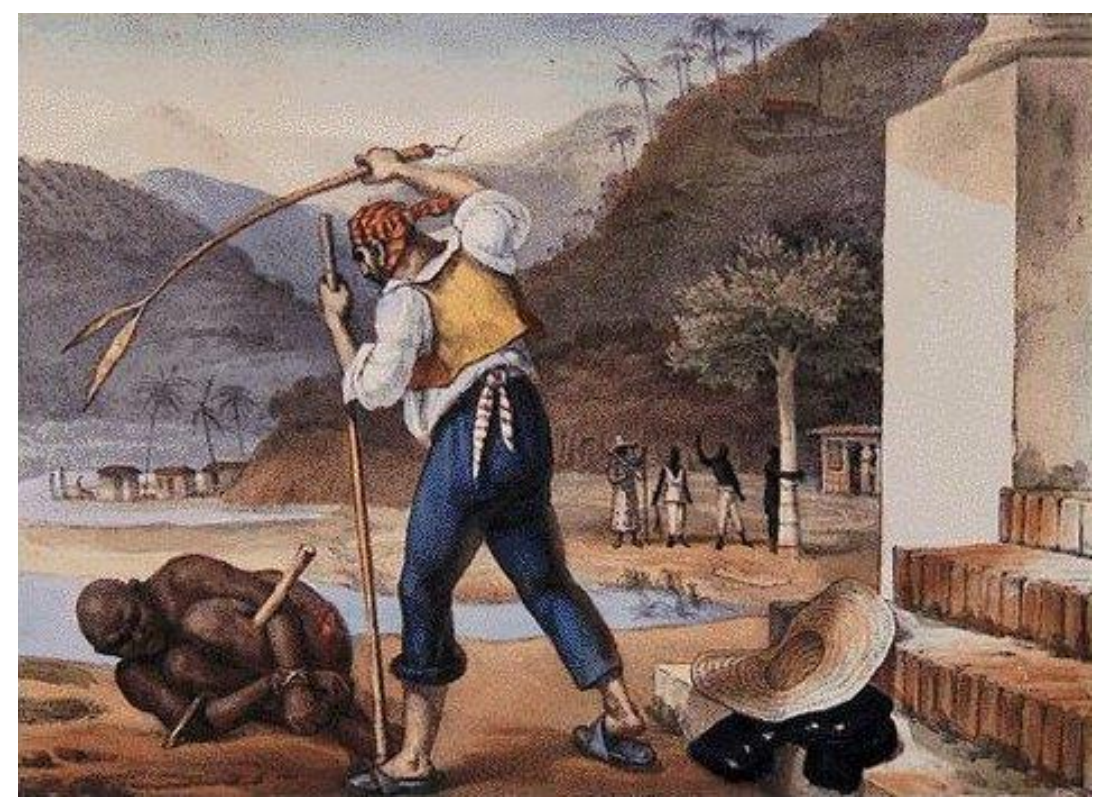

Figura 1: Jean-Baptiste Debret: Castigo de Escravo

Fonte: Wikipédia - Imagem de domínio público.

Depois de muitos anos de escola, as culturas negras me foram apresentadas como algo exótico, folclórico e primitivo, inclusive nas disciplinas ofertadas na graduação em licenciatura em Artes Cênicas. O que mudou minha forma de ver essas manifestações foi minha aproximação com a religiosidade afro-brasileira.

Um dia, um colega da faculdade me convidou para visitar um terreiro de Umbanda localizado na periferia do Distrito Federal. Muito apreensivo, revolvi acompanhá-lo e depareime com um mundo completamente misterioso, cheio de encantamentos e magias que tinha o cheiro de ervas e de charutos. A fumaça do defumador e dos tabacos misturava-se na luminosidade das velas criando uma aura mágica. As imagens e esculturas que povoavam o ambiente representavam povos indígenas e africanos de forma diferente do que tinha visto nos livros didáticos de minha infância.

Aquele primeiro contato abriu as portas da desmistificação de muitos discursos que circulam em diversos espaços sociais em que eu transito. Com o tempo, minha curiosidade se aguçou e procurei estudar mais profundamente as divindades africanas. Descobri cosmovisões 
que me foram negadas a conhecer na escola. Por entender que o Candomblé preserva mais as memórias africanas do que a Umbanda, passei a identificar-me intensamente com seus conhecimentos e práticas.

Meu encontro com as memórias vivas de minha ancestralidade africana na circularidade das culturas negras vem desconstruindo as imagens de Debret que ficaram marcadas em minhas lembranças da infância. A partir da perspectiva que reconhece que tais práticas são potentes pedagogias decoloniais, essas vivências e saberes reverberam em minhas estratégias educativas para proporcionar experiências estéticas no ensino de Arte nas escolas públicas em que atuo.

\subsection{Reverberações Decoloniais}

De 1997 a 2003, atuei como professor de anos iniciais do ensino fundamental nas escolas da rede pública do DF. Mesmo com uma visão crítica sobre termos muito usados nos livros didáticos, como "Descobrimento do Brasil", hoje eu percebo que, nesse período inicial de minha carreira, desenvolvi trabalhos com os estudantes que reforçaram as representações sociais estereotipadas que inferiorizam os povos colonizados. Durante toda minha vida aprendi a associar a escravidão aos africanos e acabei reproduzindo esse discurso durante certo período.

Somente depois de 1999, ano em que comecei a faculdade, foi que tive meu primeiro contato com um Terreiro de Umbanda. Tal fato foi marcante e me fez refletir sobre muitas de minhas práticas. A descoberta de minha própria negritude e da ancestralidade de minha família, as conversas com povos de Terreiro e as vivências ritualísticas foram essenciais para iniciar um processo de decolonização de meu próprio ser e, consequentemente, de todas minhas relações sociais.

Quando percebi que o processo de apagamento de minhas memórias ancestrais havia desconstruído boa parte de minha negritude, busquei, em minha prática pedagógica, minimizar os efeitos da colonialidade. Passei de maneira ainda intuitiva apresentar aos estudantes as referências estéticas que vão além da representação estereotipada dos sujeitos diaspóricos negros.

Para referir-se ao processo histórico de apagamento de identidades e silenciamento dos povos dominados, sobretudo os africanos, Mbembe destaca o pensamento genocida do colonizador quando afirma que o "corpo do colonizado deve tornar-se seu túmulo" (2014, p. 189). O colonialismo impõe uma dominação epistêmica em que as culturas e os saberes dos 
povos dominados são inferiorizados. Cabe ao próprio sujeito oprimido internalizar a culpa de ainda não ter alcançado a chamada modernidade estabelecida pelos padrões europeus. Nesta lógica, o dominado necessita esforçar-se para alcançar a redenção, distanciando-se de sua própria identidade considerada primitiva ou incivilizada.

À época, quando comecei a descobrir-me como pessoa negra, ainda não conhecia os Estudos Decoloniais e nem a elaboração teórica de Mbembe. No entanto, acredito que eu já sentia uma necessidade intuitiva de superação do corpo-túmulo. Em 2004, passei a dar aulas de Arte para estudantes do ensino médio. A aprovação da Lei 10.639 em 2003, que modifica o artigo 26-A da Lei de Diretrizes e Bases da Educação Brasileira - Lei n. 9.394 -, tornando obrigatório o ensino da História e Cultura Africana e Afro-brasileira nas escolas públicas e particulares do Brasil, reforçou a necessidade de estudos sobre as relações raciais. O processo de busca dos saberes afro-brasileiros se intensificou e culminou em minha iniciação no Candomblé em 2009.

Realizei algumas atividades pontuais sobre as culturas negras na sala de aula antes de minha iniciação. A criação de uma coreografia inspirada no poema Navio Negreiro, musicado por Caetano Veloso, movimentou estudantes de ensino fundamental da Ceilândia - região administrativa do DF. Alunos do ensino médio do Gama - outra região administrativa produziram uma performance a partir de imagens dos rituais afro-brasileiros. A montagem do texto dramático O Pagador de Promessa, de Dias Gomes, provocou debates intensos sobre sincretismo. Porém, percebo que meu trabalho tornou-se mais intenso depois de minha iniciação. Nunca foi meu objetivo converter ninguém ao Candomblé, até mesmo porque não se trata de uma religião de conversão. $\mathrm{Na}$ verdade, passei a perceber que muitas das manifestações culturais afro-brasileiras têm origem na religiosidade.

Para muitos povos africanos, a existência humana se constitui na continuidade entre o mundo dos vivos e o dos ancestrais. A relação entre canto, dança e percussão é utilizada para estabelecer vínculos simbólicos na circularidade da existência que engloba os humanos e os ancestrais, conforme demonstra Zeca Ligiéro (2011). Desenvolver qualquer trabalho sobre manifestações culturais afro-brasileiras sem considerar a dimensão existencial ancestral presente no continuum da vida e expressa no trio batucar-dançar-cantar reforça estereótipos folclóricos e exóticos. Na perspectiva afro-brasileira, excluir a ancestralidade dos processos de produção artística é negar as dinâmicas das concepções ontológicas dos saberes estéticos que permeiam comportamentos e práticas espetaculares. 
No ano de 2010, o trabalho com Artes Cênicas em turmas de ensino médio surgiu de discussões sobre questões raciais identitárias. Trabalhava com quinze turmas em uma escola da Ceilândia. Dava duas aulas semanais com cinquenta minutos cada. No primeiro bimestre, houve encenação de mitologias greco-romanas. No segundo, os estudantes criaram cenas a partir de histórias indígenas. No terceiro, propus a encenação de narrativas míticas do Egito ou da cultura iorubá ou a criação de coreografias baseadas em danças de matriz africana como jongo, capoeira, maracatu, maculelê, tambor de crioula, dentre outras. As opções geraram muita resistência por parte do corpo discente e calorosos debates sobre racismo.

Até então, ninguém havia se negado a trabalhar com as mitologias propostas nos bimestres anteriores. A resistência dos estudantes de apresentar o trabalho no terceiro bimestre teve motivações racistas. Uma aluna deixou de frequentar as aulas de Arte e voltou no final do bimestre com uma carta de um líder religioso fundamentalista da região solicitando à Direção da escola a liberação da estudante do trabalho realizado na disciplina. Outra estudante disse que sua religião não a permitia dançar e muito menos falar de tais mitos e lhe perguntei o que ela poderia fazer, já que todos os colegas iriam apresentar alguma cena para a avaliação bimestral. Ela me disse que cantava na igreja. Então lhe perguntei se poderia cantar uma música que falasse da cultura negra. Ela aceitou fazer uma cena estendendo roupas e cantando O Canto das Três Raças, composta por Mauro Duarte e Paulo César Pinheiro.

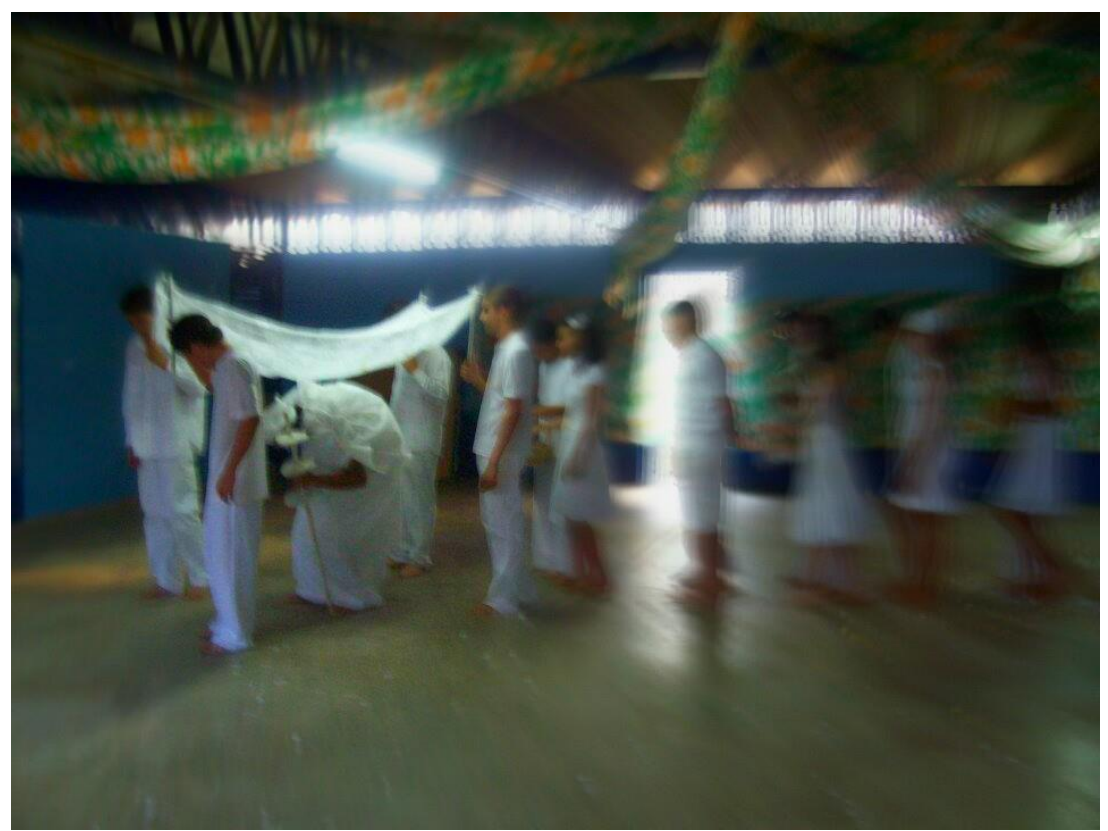

Figura 2 - Estudantes da Ceilândia realizando uma procissão para Oxalá em 2010.

Fotografia de Autor 
Durante esse processo de produção das apresentações, uma turma se sensibilizou com a recusa da maioria dos estudantes da escola de encenar aspectos religiosos da ancestralidade negra. Eles perceberam o silenciamento imposto às religiões de matriz africana e decidiram apresentar um trabalho sobre os Orixás. Pediram-me uma sugestão e então fiz a proposta de realizar uma procissão para Oxalá.

Nessa encenação, todos estavam vestidos com a cor que representa essa divindade: o branco. Um estudante ia à frente imitando movimentos corporais de Oxalufan - Oşalufan uma das representações de Oxalá, um Orixá muito velho, um dos mais antigos do panteão iorubano. No Brasil, ele anda lentamente com a coluna vertebral curvada. Os alunos confeccionaram o Opaxorô - em iorubá Opá Oșòró - espécie de um poderoso cajado enfeitado com discos e com um pássaro na ponta. Quatro pessoas seguravam uma tenda feita com tecido branco para Oxalufan caminhar debaixo. Os demais acompanhavam o cortejo jogando pétalas brancas para o alto ao som da voz de Rita Ribeiro, que musicou uma reza do Orixá da cor branca e deu o nome de Canto para Oxalá (Ver figura 2).

Em 2011 e 2012, trabalhei com as danças de matriz africana com estudantes do $6^{\circ}$ ano do ensino fundamental no Gama - DF. Usei também poesias de Oliveira Silveira para produzir algumas cenas. A resistência dos estudantes nessa escola foi de natureza estética. $\mathrm{Na}$ expectativa de discutir elementos cênicos que melhor se aproximassem da estética afro, propus ao grupo o uso de tranças, torços e acessórios. Para minha surpresa, muitas crianças reclamaram e resistiram à sugestão alegando que iriam estragar seus penteados escovados. Tal situação oportunizou a discussão em sala de aula sobre os discursos estéticos usados nos veículos de comunicação.

As representações da negritude nos meios de comunicação foram colocadas como temas das aulas. Aos poucos, os estudantes foram percebendo a relação entre o discurso do embranquecimento e as imagens bombardeadas na mídia. Utilizei propagandas de shampoo e fotografias de revistas para ilustrar a ausência de negros nas imagens. Questionei o emprego da expressão "cabelo ruim". Nessas conversas, percebi que os estudantes entenderam a importância do cabelo e da estética corporal negra na definição das identidades negras.

Em uma das aulas, quando falei da existência de reis e rainhas africanos, uma menina de onze anos me olhou com uma expressão facial de surpresa e estranhamento e me perguntou: "Ué professor! Mas existem?” Nesse debate, um estudante falou sobre a ausência de heróis negros nos filmes e nas histórias em quadrinhos. Depois de várias conversas sobre o 
assunto, o resultado foi que a grande maioria adotou a estética afro no dia da apresentação cênicas. Alguns gostaram tanto que permaneceram no estilo por mais alguns dias.

Todas essas inquietações apresentadas são referentes à negação da identidade negra. Nas escolas em que atuei, há uma predominância de sujeitos herdeiros de povos africanos. Percebemos os traços fenotípicos que determinam as características raciais. Contudo, interpreto a resistência em realizar as propostas de trabalhos em Artes Cênicas sobre as culturas de matriz africana como forma de negação de sua própria identidade afro-brasileira, como uma maneira de não se reconhecer enquanto pessoas negras.

Ao refletir sobre essas questões a partir de minha experiência com a religiosidade que me retirou desse corpo-túmulo, apontado por Mbembe, considero relevante apresentar elementos corporais identitários que observo em meus processos de significação de experiências, tendo como ponto de referência os conhecimentos produzidos nas práticas ritualísticas.

\subsection{Corpo Dançante é um Corpo Pensante}

Durante esses anos de experiência na escolarização, percebi que a questão da raça está intimamente relacionada ao controle das subjetividades. O racismo produz medos e tormentas que levam muitos sujeitos a introjetar a inferioridade imposta pelo colonizador. Com isso, nega-se o pertencimento racial e despertar-se o desejo de se tornarem seres modernos. A adoção dos padrões europeus revela o paradigma fundamentado na concepção de raça, como o que aconteceu com meus alunos que aceitaram a encenação das mitologias greco-romanas e negaram a produção de cenas a partir das históricas míticas egípcias e iorubanas.

A ideia de raça produzida no período colonial é ponto de intersecção na análise do Grupo Modernidade/Colonialidade e de Achille Mbembe em sua obra Crítica da Razão Negra (2014). Segundo Aníbal Quijano (2005), o padrão de poder estabelecido pelos europeus concentrou o domínio das formas de controle da subjetividade, da cultura, do conhecimento e da produção epistêmica. O estabelecimento de critérios científicos para se autoclassificarem como civilizados está fundamentado em mecanismos de manutenção da colonialidade organizados a partir da ideia de raça. Para Quijano, o etnocentrismo colonial e a classificação racial universal ajudam a explicar porque os povos europeus se sentem naturalmente superiores perante aos demais povos do mundo. Sobre esse assunto, Mbembe afirma: 
A "modernidade" é, na realidade, outro nome para o projeto europeu de expansão sem limites que se desenvolve a partir dos últimos anos do século XVIII. [...] Permanecerá inacabada a crítica da modernidade, enquanto não compreendermos que o seu advento coincide com o surgir do princípio de raça e com a lenta transformação deste princípio em paradigma principal, ontem como hoje, para as técnicas de dominação (2014, pp. 101 e 102).

O domínio sobre códigos alfabéticos foi considerado como elemento da supremacia das sociedades letradas sobre as consideradas primitivas, arcaicas, pagãs, ingênuas, exóticas. A crença de que existe uma escala evolutiva que considera a literacia como aspecto do pensamento abstrato gerou postulados etnocêntricos produzidos na modernidade em que Helgel, por exemplo, chegou a declarar que a África é um continente sem história, Gobineau defendeu a superioridade ariana e Kant chegou a afirmar que a miscigenação degrada a boa raça sem melhorar proporcionalmente a raça ruim (OLIVEIRA, 2012, p. 32; MUNANGA, 2006, p. 28 e 49).

Vivencio na escola o modelo de escolarização herdado da colonização, que demonstra em sua organização curricular como a racionalidade eurocêntrica é extremamente valorizada. Os currículos escolares estabelecem a constituição da ciência como instituição que valida os conhecimentos que devem ser transmitidos. A validação de saberes como verdadeiros ou falsos produz o que Boaventura Santos apontou como monocultura do saber (2009). Os epistemicídios excluem outros processos de produção de conhecimento que se utilizam da atribuição de sentidos às experiências carregadas de intuição, espiritualidade e sensibilidade.

Na perspectiva das epistemologias abissais do Norte global, o policiamento das fronteiras do conhecimento relevante é de longe mais decisivo do que as discussões sobre diferenças internas. Como consequência, um epistemicídio maciço tem vindo a decorrer nos últimos cinco séculos, e uma riqueza imensa de experiências cognitivas tem vindo a ser desperdiçada. Para recuperar algumas destas experiências, a ecologia de saberes recorre ao seu atributo pós-abissal mais característico, a tradução intercultural. Embebidas em diferentes culturas ocidentais e não-ocidentais, estas experiências não só usam linguagens diferentes, mas também distintas categorias, diferentes universos simbólicos e aspirações a uma vida melhor (SANTOS \& MENEZES, 2009, p. 52).

Para Boaventura Santos (2006, p. 78), a lógica da monocultura do saber consiste na transformação da ciência moderna e da chamada alta cultura em critérios únicos de verdade e qualidade estética. Está associada à valorização do rigor científico, onde qualquer outro saber que opera em determinadas culturas é desprezado pela cientificidade. Santos aponta o princípio de incompletude de todos os saberes, uma vez que "toda ignorância é ignorante de um certo saber e todo saber é a superação de uma ignorância particular” (Ibidem, p. 79). Essa incompletude abre possibilidade de diálogos e disputas epistemológicas entre diferentes saberes, pois cada conhecimento orienta uma prática para a superação de uma ignorância. 
Esse pressuposto básico fundamenta a proposta da substituição da monocultura do saber científico pela ecologia de saberes.

A ecologia de saberes refere-se à multiplicidade de conhecimentos em que o conjunto de epistemologias parte da possibilidade de contrapor-se à hegemonia gerada a partir da radicalização da modernidade enquanto única referência de conhecimento. Entendendo que não há epistemologias neutras, Boaventura Santos defende que os conhecimentos devem incidir nas práticas sociais. Para tanto, a ecologia de saberes requer o uso da tradução intercultural que consiste em criar uma inteligibilidade mútua entre experiências possíveis e disponíveis de diferentes culturas sem destruir sua identidade.

Nesse sentido, compreendo que o exercício de tradução intercultural consiste em uma postura dialógica com todas as formas de produção de conhecimento, inclusive a científica. Para não adotarmos uma postura radical como o cientificismo tem nos imposto durante séculos, a interculturalidade surge como alternativa para a produção de conhecimento outro pensado a partir da práxis política, conforme aborda Catherine Walsh (2007, p. 47). Segundo a autora, a interculturalidade tem significação ligada às geopolíticas de lugar e espaço de resistências de povos indígenas e negros.

A visão da interculturalidade crítica defendida por Walsh (2009) estabelece como projeto a implosão das estruturas coloniais do poder a partir da diferença. Para isso, não basta simplesmente reconhecer, tolerar ou incorporar o diferente nas estruturas estabelecidas. Essa proposta abrange as dimensões política, social, epistêmica e ética para a produção de uma sociedade radicalmente diferente. Dentre as dimensões pontuadas por Walsh, gostaria de acrescentar a dimensão estética sob a visão da Etnocenologia.

Seguindo esta premissa de romper com as estruturas coloniais a partir da valorização da produção epistêmica dos colonizados, lanço mão dos pressupostos etnocenológicos para descentralizar a visão eurocêntrica sobre as manifestações espetaculares. Nesse sentido, JeanMarie Pradier (1999) discute na Etnocenologia a categoria de práticas e comportamentos humanos espetaculares organizados, que foi inspirada na ideia de John Blacking quando definiu música como todo "som humanamente organizado". Essa nomenclatura foi adotada para permitir a ampliação das possibilidades das pesquisas em Artes Cênicas, pois é impossível enquadrar todas as manifestações espetaculares de diversas culturas na categoria teatro. 
Os estudos etnocenológicos buscam ir além da dicotomia do pensamento europeu que estabelece oposições como matéria e espírito, racionalidade e sensibilidade. Entender que o corpo dançante é um corpo pensante exige o rompimento dessa lógica. Por isso, a Etnocenologia em diálogo com outros saberes nos abre a possibilidade de produzir o conhecimento outro a partir das inúmeras manifestações culturais. Como afirma Jean-Marie Pradier: "Existem tantas práticas espetaculares no mundo que se pode razoavelmente supor que o espetacular, tanto quanto a língua e talvez a religião sejam traços específicos da espécie humana" (PRADIER, 1999).

Assim como diversos saberes foram inferiorizados pela racionalidade eurocêntrica, o mesmo acontece com os conhecimentos produzidos na estruturação de cenas no contexto cultural dos grupos colonizados. Em muitas ocasiões, os saberes estéticos cênicos foram categorizados como "pré-teatro", "teatro primitivo" e outras nomenclaturas associados aos adjetivos pejorativos como "folclórico" e "exótico".

Apesar de estarmos inseridos em uma cultura que considera o teatral em uma perspectiva eurocêntrica, onde o ator interpreta um personagem, quero ressaltar que a festa pública de Candomblé, como manifestação estética, não poderia ser categorizada como teatro. Mesmo com a existência de vários elementos cênicos nas festividades candomblecistas, falta a presença do ator como aquele que interpreta um personagem para um determinado público. Nos rituais, acredita-se na presença das próprias divindades. Nesse sentido, lanço mão da concepção de práticas e comportamentos espetaculares organizados e de espetacularidade segundo a Etnocenologia para dialogar com a atribuição de sentidos de minha experiência ritualística.

As práticas e comportamentos espetaculares organizados consistem em reverberações do pensamento. São o ato de pensar com todo corpo em um jogo que envolve criatividade, expressividade, dramaticidade, teatralidade, espetacularidade. Eles compõem o diálogo corporal nas interações com a alteridade, seja nas relações com o outro, com o sagrado ou com os objetos. Segundo a maior referência dos estudos etnocenológicos no Brasil, Armindo Bião (2009, p. 128), os rituais religiosos, a procissão, os festejos públicos, as competições esportivas, as manifestações políticas, as práticas teatrais, a performance são fenômenos sociais que reúnem coletividades e promovem a respiração social.

Sob essa perspectiva, as práticas e comportamentos humanos alcançam a dimensão do espetacular - a espetacularidade - quando o corpo necessita ter seu estado cotidiano alterado. 
Para isso, são realizados treinamentos para torná-lo virtuoso para a cena. Nesse sentido, podemos pensar nas festas de Candomblé como prática espetacular, uma vez que corpos são preparados para estabelecerem vínculos com outras dimensões da existência. $\mathrm{O}$ corpo do candomblecista se torna espetacular por ter sido preparado para ser mostrado ao outro: tanto para outros participantes do ritual como para a divindade. A dimensão estética se revela na espetacularidade do xirê como potente prática intercultural que agrega aspectos políticos, sociais, epistêmicos e éticos apontados por Walsh (2009).

A relação do sujeito com seu corpo determina em grande medida sua identidade. $\mathrm{O}$ corpo ocupa um lugar central nas manifestações culturais afro-brasileiras e não seria diferente nos rituais de Candomblé. O corpo do adepto candomblecista é mais do que um referencial biológico e não é visto como um lugar de pecado. O corpo é o altar onde o Orixá se manifesta. $\mathrm{Na}$ iniciação, há um preparo corporal para que as divindades possam usar o corpo do neófito para realizar diversas atividades. Dançar é uma das principais. Logo, o corpo é:

[...] território de significações trajetivas, identitárias e de pertencimento, onde os saberes se movimentam e se reconfiguram continuamente se recriando no diálogo permanente com a alteridade. O corpo é campo de convivências e experiências que agrega a memória ancestral, a circularidade da vida, o sentido identitário, o sentimento de pertencimento e as manifestações expressivas (AUTOR, 2015, p. 111).

Seguindo esse raciocínio, destaco a corporeidade como sistema de significações simbólicas e socioculturais que se estrutura em uma multiplicidade de movimentos corporais, pois, como afirma Renato Nogueira (2015, p. 43), "o que modifica cada interpretação e produz as mudanças no mundo são os corpos". Na afroperspectiva filosófica apresentada por Nogueira, não há uma pretensão de universalizar a visão da afrocentricidade, mas evidenciar que não devemos esquecer nossa cultura, história e ancestralidade.

Para exemplificar a corporeidade como sistema de significações, recorro à tese de doutorado de Nilma Lino Gomes. Depois de realizar uma pesquisa nos salões de beleza especializados em penteados afros na cidade de Belo Horizonte, capital de Minas Gerais, Gomes analisa a proximidade ou o distanciamento dos sujeitos nos diferentes polos sociais e raciais. Ela diz que "para alguns homens e mulheres negras, a manipulação do corpo e do cabelo pode ter o sentido da aproximação do polo branco e de afastamento do negro" (GOMES, 2006, p. 142).

Para Gomes, o tratamento dado ao cabelo pode ser considerado como comportamento social que transita entre tantos significados que vão desde à camuflagem de pertencimento 
étnico/racial, recusa de sua própria identidade, estratégia para conquistar um emprego ou aos posicionamentos politizados que adotam o cabelo crespo natural como forma de ressignificação identitária.

Segundo a autora de Sem Perder a Raiz, os sujeitos negros tiveram que politizar a beleza afro e valorizar o cabelo crespo para se contrapor ao racismo. Os movimentos de contestação que surgiram nos Estados Unidos e na África do Sul nas décadas de 1960 e 1970 influenciaram a militância política em vários países. A valorização da estética afro e a rejeição aos padrões das heranças europeias pontuaram bandeiras de lutas dessas organizações sociais. Para enfrentar os condicionamentos psicológicos provocados pelo racismo, negros e negras recorreram à potencialidade da coletividade para reconstituir a beleza negra como valor constituinte de humanidade. "O negro é lindo!", afirmava Steve Biko (1990) iniciando o Movimento de Consciência Negra na luta contra o apartheid na África do Sul para mostrar à população afro seu valor enquanto pessoa.

Além da questão política presente na corporeidade negra, quero pontuar outra consideração a partir da perspectiva das culturas afros: o raciocínio é atributo de toda corporeidade e não somente do cérebro. O corpo é arquivo da memória coletiva. Podemos encontrar essa ideia nas palavras de Nelson Inocêncio da Silva em sua tese de doutorado intitulada Museu afro-Brasil no Contexto da Diáspora:

\footnotetext{
Apesar de tal condição, o corpo africano coisificado, alvo de tantas mazelas, era também um arquivo que carregava o registro das experiências passadas, as quais foram muito úteis na elaboração das estratégias de sobrevivência no Novo Mundo. Os corpos subalternizados existiam para além da subalternização e na ausência de pertences que não puderam ser trazidos na longa viagem sem volta os corpos adquiriram substancial importância como referencial mnemônico das coletividades aviltadas. Devemos considerar que, apesar de africanos escravizados terem sido obrigados a se submeter a ritos destinados a proporcionar a desvinculação de tudo aquilo que viveram anteriormente, a exemplo do ritual em torno da "árvore do esquecimento", um intenso processo de ressignificação iniciou-se a partir desse momento (2013, p. 146).
}

O ritual de dar voltas em torno da árvore do esquecimento ao qual Silva se refere, assemelha-se ao processo de apagamento dos nomes e das identidades africanas nos batismos cristãos. Dar voltas para esquecer o passado e desconstruir o pertencimento cultural é a tentativa de esvaziamento dos corpos, de sua história, de sua memória e sua cultura, assim como salienta o autor (SILVA, 2013, p. 149). Esvaziá-los para controlá-los com mais facilidade. Esses mecanismos de controle revelam-se na proibição das danças, cantos, músicas e outras diversas manifestações culturais negras desde o início do Brasil Colônia. 
Para sobreviver à rede de violências colonial, homens e mulheres africanos ressignificaram, no Brasil, diversos rituais praticados em África para restituir a si próprios a humanidade negada pelo colonizador, dialogando com a espetacularidade presente nas festas públicas, para apresentar à Comunidade um corpo outro, um corpo-altar.

\subsection{As Noções de Corpo e de Pessoa da Cultura Iorubá que Circulam no Brasil}

Para compreender as noções de corpo e de pessoa dentro da lógica ritualística candomblecista de nação Ketu, recorro à pesquisa de vinte anos de Síkírù Sàlámi e Ronilda Iyakemi Ribeiro, que resultou na obra Exu e a Ordem no Universo (2011, p. 33). Conforme estes autores, em diversas culturas africanas, a constituição do ser humano é resultante de uma justaposição coerente de diversas partes. Esses diferentes componentes da pessoa estabelecem relações entre si e com as forças cósmicas.

A pessoa é tida como resultante da articulação de vários elementos, alguns estritamente individuais e alguns outros simbólicos. Os elementos herdados se situam em uma linguagem familiar e clânica, enquanto os elementos simbólicos a posicionam no ambiente cósmico, mítico e social (SÁLÁMI \& RIBEIRO, 2011, p. 33). Desta forma, cada pessoa é uma organização complexa de elementos naturais, exposta às transformações do tempo. A pessoa reconhece a si mesma em sua unidade/pluralidade mesmo passando por diversas mutações cósmicas e temporais e, também, é reconhecida pelos outros como sujeito permanente dotada de identidade e história pessoal.

Segundo Sálámi e Ribeiro, os iorubás concebem a pessoa formada pelos seguintes princípios vitais: ará, òjiji, okàn, èmi e orí. Ará é o corpo físico; òjíji é a representação visível da essência espiritual que acompanha o homem durante toda a vida, morrendo junto com ará, embora não sendo enterrado com ele. Qkan, cujo significado é coração, possui profunda relação com o sangue e é a parte considerada a sede da inteligência e do pensamento intuitivo, a alma e a fonte originária de toda ação. Ėmi, princípio vital, sopro vital, é intimamente relacionado à respiração, mas não se reduz a ela, pois se diz por ocasião da morte de uma pessoa que èmmi foi embora. Significa também espírito ou ser. [...] Orí, literalmente cabeça, designa orí inú, a cabeça interior, a grande responsável pelo destino pessoal, cultuada entre outras divindades, mas sendo, de fato, a mais importante de todas. Diz um provérbio iorubano que "a cabeça de uma pessoa faz dela um rei". Orí é considerado a mais importante divindade dentro do panteão iorubá, pois somente ele "pode acompanhar o devoto numa viagem sem volta para além dos mares” (PRANDI, 2001, pp. 476-481). 
Dentro da lógica da cosmovisão dos que foram chamados de nagôs pelos colonizadores, a morte é representada por um Orixá nomeado Ikú. Segundo Juana Elbein dos Santos (2007), Ikú está profundamente associado ao mito da gênese da humanidade e à terra:

\begin{abstract}
Quando Olórun procurava matéria apropriada para criar o ser humano, todos os ebora partiram em busca da tal matéria. Trouxeram diferentes coisas: mas nenhuma era adequada. Eles foram buscar a lama, mas ela chorou e derramou lágrimas. Nenhum ębora quis tomar da menor parcela. Mas ikú, Q̀jèggbé-Alásoapareceu, apanhou um pouco de lama - eerúpé - e não teve misericórdia de seu pranto. Levou-o a Olódùmarè, que pediu a Òrișàlá e a Olúgama que o modelaram e foi Ele mesmo quem lhe insuflou o seu hálito. Mas Olódùmarè determinou a Ikú que, por ter sido ele a apanhar a porção de lama, deveria recolocala em seu lugar a qualquer momento, e é por isso que Ikú sempre nos leva de volta para a lama (SANTOS, 2007, p. 107).
\end{abstract}

No sistema cosmogônico iorubano, a existência transcorre em dois níveis: o àiyé - o mundo físico -, onde vivem os seres vivos - os ará-àiyé. O outro nível da existência é chamado de orun - o espaço sobrenatural -, o além onde habitam os orixás e ancestrais - os ará-orun. O orun é um mundo paralelo ao espaço físico e se diferencia da concepção de céu/paraíso do Cristianismo. Trata-se de outra realidade. Acredita-se que tudo o que existe no orun tem sua ou suas representações materiais no àiyé (SANTOS, 2007, p. 54). Segundo essa lógica mítica, o corpo humano - ará-àiyé - é constituído pelo elemento terra, combinado com outros elementos naturais.

Conforme os estudos de Marco Aurélio Luz (1995, p. 52), a matéria com que são moldados os seres humanos é chamada pelos iorubás de İpòri ou Òkè İpori. O local de onde foi retirado e a qualidade do İpòri escolhida pela divindade que a apanhou determinam o Orixá regente do orí de uma pessoa. Sobre esse assunto, Juana Elbein dos Santos (2007, p. 205) afirma que: "Esse conceito é muito importante, porque estabelece uma série de relações entre o indivíduo e sua matéria de origem mítica". O termo İpòri indica o tipo de material com o qual é modelado o orí de cada pessoa e a partir dessa matéria ancestral é que são feitos os rituais adequados para cada tipo de constituição identitária.

Segundo Santos, a entidade suprema para os iorubás, o grande detentor de três forças primordiais - ìwà, àsę, àbá - é chamado de Qlórun, ou seja, o senhor do orun. Ele transmitiu aos Irúnmalè as combinações desses três elementos para manter a atuação dos mesmos em diferentes domínios. Os Irúnmalè são classificados em dois tipos: os Òrișà, divindades cuja existência remete aos primórdios do universo, e os ancestres ou Égún, espíritos de seres humanos. "Se os ancestrais são os espíritos dos ará-àiyé, estes, por sua vez, 
renascem dos ancestrais; sua matéria de origem - lama tirada da terra - é a mesma. Ikú restitui à terra o que lhe pertence, permitindo, assim, os renascimentos [...]” (SANTOS, 2007, p. 107).

A ideia de continuum entre o mundo dos vivos e dos ancestrais está presente em muitas culturas africanas e intimamente relacionada com a concepção de circularidade. Existem intensos fluxos e refluxos culturais que se encontram nas encruzilhadas para depois se redimensionarem e tomarem diversas direções para novos (re)encontros. Não pretendo apresentar uma ideia de um determinado povo e induzir a uma suposta homogeneidade nas concepções das diversas civilizações do continente africano. Contudo, devido às condições históricas, muitos grupos vindos da África para o Brasil tiveram que redimensionar as noções de corporeidade e de pessoa para reconstituírem suas identidades como reação às violências coloniais.

Nesse sentido, os candomblés reorganizaram as identidades negras em suas práticas ritualísticas. A associação de um sujeito com sua matéria ancestral provoca identificações que (re)estruturam os elementos constituintes do ser humano. Sendo assim, podemos considerar que a noção de corporeidade foi fundamental para que os africanos e seus descendentes pudessem resistir e sobreviver ao genocídio vivido no mundo colonial.

\subsection{Corporeidades Identitárias no Corpo-altar}

Contextualizado em relações de poder permeadas pela rede de violências que levam o colonizado a um corpo-túmulo, o sujeito afro tem enfrentado o genocídio imposto nos últimos séculos, tendo sua própria corporeidade como forma de resistência. Rodas de samba, de capoeira, de jongo, de candomblé, de maculelê, dentre tantas outras, constituíram-se como territórios de quilombismos (NASCIMENTO, 2002) em que o corpo, o ará-àiyé, revela-se como elemento central de toda produção de conhecimento.

Como vimos anteriormente, o Ípori é o que determina qual divindade iorubá deverá ser reverenciada pelo devoto por fazer parte de sua constituição corporal ancestral. Nos ritos de iniciação, o corpo do neófito é purificado e ressignificado com elementos simbólicos pertencentes ao universo do seu Orixá. Espera-se que essa purificação permita a aproximação da divindade. Há iniciados que não incorporam - ekéji e ogan, mas que sentem a energia dos Orixás de outras maneiras. Há iniciados chamados de ìyà wó, que passam a ter seu corpo controlado por forças consideradas sagradas. 
A partir da noção de espetacularidade - produção de um corpo para ser visto pelo outro - o corpo do iniciado se torna um corpo-altar. Esse corpo é sacralizado para abrir os canais de comunicação com o orun em diversos rituais de purificação. Tal concepção se contrapõe ao conceito de corpo-túmulo, uma vez que o africano e/ou afrodescendente sente em sua corporeidade uma agência que o mobiliza para enfrentar tantas violências. Podemos considerar que essa força mobilizadora que descentraliza o sujeito e o reconecta com sua ancestralidade, que transcende a humilhação da escravidão, é o que cria condições de estabelecer vínculos com sua própria humanidade que lhe foi negada pelo colonizador.

Em um xirê, há batuque, canto e dança saudando todos os Orixás cultuados no Brasil. Muitos adeptos, principalmente os mais novos, incorporam quando seu Orixá está sendo reverenciado. Outros recebem em seus corpos a energia da divindade quando Xangô está sendo homenageado na roda. Os corpos dos yiàwó, controlados pelos Orixás, passam a mover-se ao som dos tambores. Cada Orixá tem um ou mais ritmos específicos. Cada divindade está associada a um ou mais elementos da natureza. Geralmente, os movimentos dos corpos dos devotos tomados pelos ancestrais divinizados apresentam características simbólicas do elemento que este representa.

Para exemplificar a relação da corporeidade com as identidades que se manifestam na estética utilizada no xirê, passo a descrever alguns aspectos de quatro Orixás que selecionei usando o critério meramente ilustrativo a partir da ligação dessas divindades com cada um dos elementos da natureza. A associação da água, terra, ar e fogo aos princípios míticos e simbólicos são articulados com as dimensões política, social, epistêmica, ética e estética do corpo. O panteão iorubano é muito mais extenso. As divindades citadas foram escolhidas a partir de um recorte feito a intenção de representar como acontece o processo dinâmico identitário da civilização afro-brasileira.

Oxum é um Orixá feminino. Está relacionada à água doce: rios, cachoeiras, nascentes, lagoas. "Òșun é a genitora por excelência, ligada particularmente à procriação e, nesse sentido, ela está associada à descendência no àiyé. Ela é a patrona da gravidez" (SANTOS, 2007, p. 85). Geralmente, o ritmo de suas cantigas é o ijexá. Os movimentos da dança de Oxum, em muitos momentos, são tranquilos como a água que desliza no rio. Algumas vezes, o ritmo pode ser agitado, assim como a água corre ligeira em determinados locais. Em seus atos de dança, Oxum apresenta uma gestualidade que remete à gravidez/gestação, ao banho no rio, ao uso de joias como pulseiras, colares, brincos, coroa. Suas narrativas míticas revelam o 
poder de sedução, encantamento e beleza de Oxum. O uso do espelho - àbèbé - é o símbolo que representa essa característica. O àbébé pode ser usado como uma arma, pois Oxum também é guerreira, assim como mostra alguns atos de sua dança.

\author{
Oxum era a rainha \\ Na mão direita tinha \\ O seu espelho que vivia a se mirar \\ (Canto para Oxum - Vinícius de Moraes e Toquinho)
}

Na maioria das vezes, a divindade dos rios e cachoeiras se mostra meiga e carinhosa com os devotos. É considerada a dona do Candomblé, pois, em sua mitologia, ela cria os ritos necessários para que os Orixás possam dançar nos corpos de seus filhos (PRANDI, 2001, p. 526). Esse feito está associado com o reestabelecimento do culto aos deuses iorubanos depois que os colonizadores os proibiram de exercer sua religiosidade. A separação mítica do àiyée do orun e o reestabelecimento dos rituais ensinados por Oxum para a preparação do corpoaltar demonstram a forma estratégica encontrada pelos iorubás para reconstituírem sua religiosidade diante das proibições.

A mitologia iorubana aponta Xangô como rei, Aláàfin Òyó, que foi divinizado após sua morte tornando-se Orixá do fogo, do trovão e da justiça. As narrativas míticas estão repletas de elementos que remetem ao seu caráter masculino e viril. Nas rodas dos Candomblés, Xangô é saudado com o canto acompanhado com o toque dos três atabaques de tamanhos diferentes em um ritmo conhecido como Alujá, uma cadência rítmica que aumenta gradativamente até chegar a uma execução rápida que expressa força e dá uma sensação de "esquentar" a dança. O atabaque maior - o rum - é repicado vigorosamente em uma alusão aos trovões do Orixá. Assim, os participantes de uma roda, que dançam para Xangô, cantam e executam movimentos corporais que expressam o aspecto guerreiro e quente desta divindade.

Qbàlúaiyé é um Orixá de poder extraordinário ligado à morte e à terra. Quando presente nos corpos de seus devotos, deve ser coberto por uma vestimenta feita de palha da costa - uma espécie de ráfia africana. Divindade associada ao controle das doenças como varíola, pestes, lepra, dentre outras, e, por isso, é extremamente respeitado e temido. Seu nome significa " $Q b a+o l u ́+$ àiyé $=$ Rei de todos os espíritos do mundo, detém e lidera o poder dos espíritos e dos ancestrais que o seguem e ele oculta sob a ráfia o mistério da morte e do renascimento, o mistério da gênese" (SANTOS, 2007, p. 99). A dança de Obaluaê é 
marcada pelo ritmo chamado opanijé, que é lento, pesado, triste e quebrado. Seus atos de dança remetem às narrativas míticas que acontecem nas profundezas da terra.

Destaco a figura de Oxalá, conhecido também como Òrișànlá, que possui em si os princípios masculino - Obàtálá - e feminino - Odùduwà. Oșàlá pertence ao grupo dos òrişá funfun, ou seja, os orixás que só usam branco e que estão associados aos mitos da criação do mundo. O universo é representado por uma cabaça, cuja metade está ligada ao feminino e a outra ao masculino. A cabaça é símbolo do útero, do poder geracional e criador.

A representação mais conhecida do universo, da unidade que constitui o àiyé e òrun é sobretudo simbolizada por uma cabaça formada por duas metades unidas, a metade inferior representando o àiyé, a metade superior òrun, e contendo em seu interior uma série de elementos. Antes de examinar essa representação conhecida com o nome de igbá-odù ou igbádù - assim como uma série de símbolos materiais estruturados à sua imagem - é importante deter-nos em dois mitos genéticos, os dos elementos cósmicos e o da terra, que permitirão uma melhor interpretação dos elementos-signos do ibádù em função do símbolo como um todo. Numa densa síntese, a história nos informa que nos primórdios existia nada além de ar; Olórun era uma massa infinita de ar; quando começou a mover-se lentamente, a respirar, uma parte do ar transformou-se em massa de água, originando Òrìșànlá, o grande òrișà-Funfun, òrì̀̀a do branco. $\mathrm{O}$ ar $\mathrm{e}$ as águas moveram-se conjuntamente e uma parte deles mesmos transformou-se em lama. Dessa lama originou-se uma bolha ou montículo, primeira matéria dotada de forma, um rochedo avermelhado e lamacento. Olórun admirou essa forma e soprou o montículo, insuflando-lhe seu hálito e dando-lhe vida. Essa forma, a primeira dotada de existência individual, um rochedo de laterita, era Esşú, ou melhor, o proto-Ėsú, Ėşú Yangí [...] (SANTOS, 2007, p. 59).

Relacionado aos elementos ar e água, Oxalá possui duas formas de manifestação no àiyé: Oxalufan e Oxaguian. Essas duas qualidades de Oxalá dançam de forma distintas. Oxalufan, o mais velho, é mais lento, desloca-se muito vagarosamente pelo espaço carregando seu opaxorô. Geralmente, usa-se um pano para cobri-lo para que ninguém pise em sua sombra durante seu deslocamento. O ritmo tocado em sua homenagem é chamado de igbin, que significa caracol, um dos animais que o simboliza. É um ritmo executado lentamente com batidas fortes.

Na citação acima, vemos que a individualização, fundamentada no surgimento mítico de Exu como o primeiro ser criado, expressa a preocupação que os iorubás possuem sobre o aniquilamento total de seu ser. Segundo Santos, o maior temor do iorubano é ser completamente reabsorvido pela massa e não renascer nunca mais (2007, p. 76). Talvez, nesse sentido, essa foi a maior violência provocada pela colonização: a de tentar destituir a identidade de um povo. Porém, a celebração de um corpo-altar permitiu a produção de resistências à rede de violências que objetiva levar o colonizado ao corpo-túmulo. 
Catherine Walsh (2013, p. 25), na introdução da obra Pedagogías Decoloniales, afirma que o pedagógico e o decolonial adquirem sua razão e sentido político, social, cultural e existencial a partir do horizonte histórico de larga duração de invasões e violências praticadas para garantir a manutenção do poder colonial. Segundo a autora, as estratégias, práticas, metodologias das lutas, rebeldias, insurgências, organização e ação dos povos originários das terras renomeadas de "América" pelos invasores e dos afrodescendentes constituem as pedagogias decoloniais.

Nesse sentido, as vivências estéticas proporcionadas no xirê são potentes pedagogias decoloniais. Por isso, proponho que a dimensão estética possa ser considerada e acrescentada às dimensões sugeridas por Walsh, uma vez que sistemas de signos e símbolos são produzidos a partir das experiências corporais. A corporeidade negra vista a partir da cosmovisão iorubana agrega elementos estéticos que ressignificam e decolonizam a cosmogonia do ser e do saber.

\section{Conclusões}

Neste trabalho, apresentei conhecimentos estéticos afro-brasileiros que se constituem como potentes pedagogias decoloniais, uma vez que consistem em estratégias, práticas e metodologias de lutas, resistências, insurgências, organização e ação da população negra perante as violências coloniais. Tive como objetivo propor reflexões sobre as práticas $e$ comportamentos humanos espetaculares organizados oriundos das noções de corporeidades que circulam no xirê e que ressignificam identidades. Portanto, a abordagem intercultural apontou a decolonialidade cosmogônica do ser e do saber a partir de uma visão dos elementos estéticos.

Ao considerar a interculturalidade como proposta que abrange dimensões política, social, epistêmica e ética na perspectiva apontada por Catharine Walsh, propus olharmos para aspectos da estética afro-brasileira na significação das experiências em rodas de Candomblé. Essa necessidade surge a partir da definição de minha própria identidade racial, quando vivenciei em meu corpo negro a associação de características de elementos míticos, cósmicos e ancestrais aos aspectos humanos feita pelos iorubás. Nesse sentido, a produção de saberes significa potente estratégia de superação das violências impostas aos povos colonizados.

Logo, podemos concluir que os movimentos corporais usados nas danças dos Orixás simbolizam nossas origens míticas a partir das características dos elementos da natureza 
intimamente vinculados à nossa humanidade: água-maternidade-feminilidade-belezaencantamento-resiliência; fogo-masculinidade-vigor-justiça; terra-vida-morte-doença-curatemor; ar-criação-ancestralidade-paciência.

A combinação do canto, da dança e do batuque é usada para estabelecer os vínculos simbólicos no círculo social entre vivos e mortos. A circularidade presente na continuidade entre esses dois níveis da existência exige encararmos a vida de forma transcendente, em que nossa ancestralidade vai além da ideologia que racializa e inferioriza o outro.

Mesmo diante de toda vigilância, de toda violência policial e de todos os discursos racistas que clamam até hoje pela extirpação dos hábitos africanos, os corpos dançam, festejam, batucam, rezam, sambam em verdadeiros atos de resistências. Mesmo sendo representado de formas pejorativas em discursos midiáticos ou em conversas cotidianas, o corpo negro se presentifica em um campo de vivências que desloca os sentidos das relações identitárias. Enquanto as manifestações culturais afro-brasileiras despertam os sentimentos de pertencimento e procuram exaltar a beleza do corpo negro, a escola vem desempenhando um papel no sentido contrário, reforçando os estereótipos marcados pelos traços raciais.

A ideia de corpo-túmulo apresentada pela lógica colonial pode ser superada pela valorização do corpo-altar. Se o corpo negro foi, no decorrer dos séculos de colonização, esvaziado de sua história, de sua memória coletiva, de sua beleza, representado pejorativamente de forma a fragilizar os sujeitos, a resistência consiste em invertermos esse processo produzindo saberes com o corpo. Os africanos e seus descendentes apresentam em suas práticas corporais o conhecimento outro, o corpo outro para transcender ao corpo coisificado, animalizado, humilhado. Essa é uma das tantas reações para reconstituirmos nossa humanidade negada na colonialidade. Sem a consciência de nossa identidade, sem conhecermos nossa história, sem a valorização de nossa ancestralidade, estamos caminhando na linha tênue da incompreensão de nós mesmos.

\section{REFERÊNCIAS}

ARAÚJO, Ubiratan Castro de. A Chegada dos Sem Nome: Uma Reportagem Histórica. In: Revista Palmares em Ação, vol. 1, n. 1, pp. 46-53, 2002.

BALLESTRIN, Luciana. A América Latina e o giro decolonial. IN: Revista Brasileira de Ciência Política. n. 11, Brasília, maio-agosto de 2013, pp. 89-117. 
BIÃO, Armindo Jorge de Carvalho. Etnocenologia e a Cena Baiana: Textos Reunidos. Salvador: P\&A Gráfica e Editora, 2009.

A Comunicação nas Encruzilhadas da Esfinge, de Hermes, Mercúrio, Exu e Maria Padilha: Ditos e Não-ditos, Interditos e Mal-entendidos. In: Revista Famecos, Porto Alegre, n. 40, dezembro de 2009a.

BIKO, Steve Bantu. Escrevo O Que Eu Quero. - São Paulo, SP: Editora Ática, 1990.

CAPUTO, Stela Guedes. Educação nos Terreiros: e como a escola se relaciona com crianças de candomblé. - $1^{\text {a }}$ ed. - Rio de Janeiro: Pallas, 2012.

DOMENICI, Eloisa. A Pesquisa das Danças Populares Brasileiras: Questões Epistemológicas para as Artes Cênicas. IN: Cadernos do GIPE-CIT: Grupo Interdisciplinar de Pesquisa e Extensão em Contemporaneidade, Imaginário e Teatralidade. Programa de Pós-Graduação em Artes Cênicas - Salvador: UFBA, n. 23, pp. 7-18, out. 2009.

FANON, Franz. Os Condenados da Terra. Juiz de Fora: Editora UFJF, 2005.

FORTIN, Silvie. Contribuições Possíveis da Etnografia e da Auto-etnografia para a Pesquisa na Prática Artística. In: Revista Cena, Programa de Pós-graduação em Artes Cênicas do Instituto de Artes da Universidade do Rio Grande do Sul, n. 7, pp. 77-88, 2009.

FOUCAULT, Michel. A Ordem do Discurso: aula inaugural no Collège de France pronunciada em 2 de dezembro de 1970. 21. ed. São Paulo: Loyola, 2011.

Arqueologia do Saber. - $3^{\text {a }}$ ed. - Rio de Janeiro: Forense-Universitária, 1987.

. Microfísica do Poder. 2. ed. Rio de Janeiro: Paz e Terra, 2015.

Vigiar e Punir: nascimento da prisão. 39. ed. Petrópolis, RJ : Vozes, 2011.

GOMES, Nilma Lino. Corpo e Cabelo como Símbolos da Identidade Negra. [On-line], 2012. Disponível em: http://www.acaoeducativa.org.br/fdh/wp-content/uploads/2012/10/Corpoecabelo-como-s\%C3\%ADmbolos-da-identidade-negra.pdf. Acessado dia 30/10/2015.

Sem Perder a Raiz: Corpo e Cabelo como Símbolos da Identidade Negra. Belo Horizonte: Autêntica, 2006.

LIGIÉRO, Zeca. Corpo a Corpo: Estudo das Performances Brasileiras - Rio de Janeiro: Garamond, 2011.

LUZ, Marco Aurélio de Oliveira. Agadá: Dinâmica da Civilização Afro-brasileira. Salvador: Centro Editorial e Didático da UFBA: Sociedade de Estudos da Cultura Negra no Brasil, 1995.

MBEMBE, Achille. Crítica da Razão Negra. - Lisboa: Antígona Editores Refractários, 2014.

MUNANGA, Kabengele. Negritude: Usos e Sentidos. São Paulo: Editora Ática, $2^{a}$ ed., 1988. Rediscutindo a Mestiçagem no Brasil: Identidade Nacional Versus Identidade Negra. 2 ed. - Belo Horizonte: Autêntica, 2006. 
NASCIMENTO, Abdias. Quilombismo. - $2^{\mathrm{a}}$ ed. - Brasília/Rio de Janeiro: Fundação Cultural Palmares/OR Editor Produtor Editor, 2002.

OLIVEIRA, Eduardo David de. Filosofia da Ancestralidade como Filosofia Africana: Educação e Cultura Afro-brasileira. In: Revista Sul-americana de Filosofia e Educação, Brasília, n. 18, pp. 28-47, maio-out/2012

QUIJANO, Anibal. Colonialidade do poder: eurocentrismo e América Latina. IN: A colonialidade do saber: eurocentrismo e ciências sociais. Perspectivas latino-americanas. Edgardo Lander (org). Colección Sur Sur, CLACSO, Ciudad Autónoma de Buenos Aires, Argentina. setembro 2005. pp.227-278.

PRADIER, Jean-Marie. Etnocenologia. IN: BIÃO, Armindo Jorge de Carvalho; GREINER, Christine (orgs.). Etnocenologia: textos selecionados. - São Paulo: Annablume, 1999.

PRANDI, Reginaldo. Mitologia dos Orixás. - São Paulo: Cia das Letras, 2001.

SÀLÁMI, Síkírù \& RIBEIRO, Ronilda Iyakemi. Exu e a Ordem do Universo. São Paulo: Editora Oduduwa, 2011.

SANTOS, Boaventura de Souza \& MENESES, Maria Paula (orgs.). Epistemologias do Su. Coimbra: Edições Almedina, 2009.

SANTOS, Juana Elbein dos. Os Nàgó e a Morte: Pàde, Asèsè e o Culto Égun na Bahia.12. ed. - Petrópolis: Vozes, 2007.

SILVA, Nelson Fernando Inocêncio da. Museu afro-Brasil no Contexto da Diáspora: Dimensões Contrahegemônicas das Artes e das Culturas Negras. Tese de doutorado em Artes pela Universidade de Brasília, Brasília, 2013.

. Representação Visual do Corpo afro-descendente. In: PANTOJA, Selma (org.) et alii. Entre Áfricas e Brasil. - Brasília: Paralelo 15 - São Paulo, Marco Zero, 2001.

WALSH, Catherine. Interculturalidad y Colonialidad del Poder. Um pensamento y posicionamento "otro" desde la diferencia colonial. IN: CASTRO-GOMEZ, Santiago \& GROSFOGUEL, Ramón. El Giro Decolonial: reflexiones para uma diversidade epistémica más allá del capitalismo global. Bogotá: Siglo del Hombre Editores, 2007.

Interculturalid y (de)colonialidade: Perspectivas críticas y políticas. Visão Global, Joaçaba, v. 12, n. 1-2, p.61-74, jan./dez. 2012.

. Interculturalidade e Educação Intercultural. IN: Seminário "Interculturalida y Educación Intercultural”. 2009. Instituto Internacional de Integración del Convenio Andrés Bello, La Paz, 9-11 de marzo de 2009.

Pedagogías Decoloniales: Prácticas insurgentes de resistir,(re)existir y (re)vivir. Tomo I - Quito-Ecuador: Ediciones Abya-Yala, 2013. 